\title{
Fibrinogen- Albumin Ratio: An Intriguing Relationship for Assessing Trombosis Risk and Suspicious Effect on Blood Viscosity
}

\author{
Ismail Sapmaz ${ }^{1^{*}}$, Tonguc Saba ${ }^{1}$, Cevahir Haberal ${ }^{1}$, Aydin Toktamis ${ }^{2}$, Melis Cakmak ${ }^{3}$, Davran \\ Cicek $^{4}$ \\ ${ }^{1}$ Alanya Research Center Cardiovascular Surgery, Baskent University, Antalya, Turkey \\ ${ }^{2}$ Alanya Research Center Family Medicine, Baskent University, Antalya, Turkey \\ ${ }^{3}$ Alanya Research Center Anesthesiology, Baskent University, Antalya, Turkey \\ ${ }^{4}$ Alanya Research Center Cardiology, Baskent University, Antalya, Turkey
}

A R T I C L E I N F O

Article type:

Letter to Editor

\section{Article history:}

Received: 8 May 2011

Revised: 22 May 201

Accepted: 6 Jan 2011

Keywords:

Fibrinogen

Albumins

Blood Viscosity

\section{Dear Editor,}

Hemorheological factors, such as viscosity, are significant in determining blood flow characteristics and play an important role in the pathogenesis of thrombotic events and, therefore, cerebrovascular diseases. The viscosity of fluids depends on; particle concentration, shape of the particles, $\mathrm{pH}$ of the fluid, and temperature. Blood includes many different kinds of proteins such as; fibrinogen, albumin and globulins. Plasma viscosity and hematocrit values are the major determinants of whole blood viscosity (1-3). It should be bought to one's attentiu on, that although albumin comprises more than half of the total serum proteins (4), its effect on blood viscosity is very low (5). This is an inverse situation according to our physical knowledge of fluid viscosity. An interesting study by Lacombe et al. (6) showed that an elevation in fibrinogen concentration, leads to a more aggregated

\footnotetext{
* Corresponding author: Ismail Sapmaz, Alanya Research Center Cardiovascular Surgery, Baskent University, Antalya, Turkey. Tel: +90-5335158084, Fax:+90-2425115563,E-mail: sapmazismail@yahoo.com.tr

DOI: $10.5812 /$ icrj.4418

Copyright @2011 Kowsar Corp. All rights reserved.
}

- Please cite this paper as:

Sapmaz I, Saba T, Haberal C, Toktamis A, Cakmak M, Cicek D. Fibrinogen- Albumin Ratio: An Intriguing Relationship for Assessing Trombosis Risk and Suspicious Effect on Blood Viscosity. Int Cardiovasc Res J.2011.5(4):153-4. DOI: 10.5812/icrj.4418

Copyright $\odot 2011$ Kowsar Corp. All rights reserved.

structure in red blood cell suspensions. Immediately after the albumin was added, increased aggregability of red blood cell was improved. It sems that there is a negative correlation between erythrocyte aggregability and plasma albumin.

Here, we present, retrospectively identified patients whose albumin and fibrinogen levels had been studied in our center between 2001-2010. We excluded patients who were; younger than 18 years old, pregnant, anticoagulant therapy users, women who take oral contraceptives or suffering from any of the following conditions; any malignant disease, diabetes mellitus, liver disease, any hematologic disease, and acute or severe infections. Age, sex, hematocrits, and white blood cell count parameters were noted in addition to; albumin, fibrinogen and the presence or absence of a cardiovascular event. Two groups were formed. Group A: Patients who had had no cardiovascular event $(n=32)$. Group B: Patients who had had a cardiovascular event $(n=27)$. There was no significant difference between the two groups by gender (Group A: 18 women, 14 men. Group B: 13 women and 14 men). Hematocrit levels did not differ significantly be- 
tween the two groups $(P>0,05)$, however, there was a significant $(P<0,05)$ difference between the two groups in their mean ages, and plasma fibrinogen levels were significantly higher in Group B $(P<0,05)$. Plasma albumin levels were significantly lower in Group $B(P<0,05)$. The albumin/fibrinogen ratio was considerably higher in group B. Fibrinogen was higher in Group B, inversely; albumin levels were lower in this group.

In conclusion, we speculate that albumin levels should be taken into consideration while exploring the influence of fibrinogen on cardiovascular disease. We also believe that the influence of albumin on blood viscosity and cardiovascular disease should be investigated in more detailed studies.

\section{Financial Disclosure}

None declared.

\section{References}

1. Kesmarky G, Kenyeres P, Rabai M, Toth K. Plasma viscosity: a forgotten variable. Clin Hemorheol Microcirc. 2008;39(1-4):243-6.

2. Lowe GD, Drummond MM, Forbes CD, Barbenel JC. The effects of age and cigarette-smoking on blood and plasma viscosity in men. Scott Med J.1980;25(1):13-7.

3. Lowe GD, Fowkes FG, Dawes J, Donnan PT, Lennie SE, Housley E. Blood viscosity, fibrinogen, and activation of coagulation and leukocytes in peripheral arterial disease and the normal population in the Edinburgh Artery Study. Circulation. 1993;87(6):1915-20.

4. Busher JT. Serum Albumin and Globulin. In: Walker HK, Hall WD, Hurst JW, editors. Clinical Methods: The History, Physical, and Laboratory Examinations. 3 rd ed. Boston.Butterworth; 1990.

5. de Simone G, Devereux RB, Chien S, Alderman MH, Atlas SA, Laragh JH. Relation of blood viscosity to demographic and physiologic variables and to cardiovascular risk factors in apparently normal adults. Circulation. 1990;81(1):107-17.

6. Lacombe C, Bucherer C, Ladjouzi J, Lelievre JC. Competitive role between fibrinogen and albumin on thixotropy of red cell suspensions. Biorheology.1988;25(1-2):349-54. 